\title{
Surface-flow wetland for water reclamation at Batamindo Industrial Park
}

\author{
Chris Salim ${ }^{1, *}$, Andita Rachmania ${ }^{1}$, and Rahma Dewi $^{2}$ \\ ${ }^{1}$ Surya University Department of Environmental Engineering, 15810 Tangerang, Indonesia \\ ${ }^{2}$ PT. Batamindo Investment Cakrawala, Wastewater Treatment Plant \& Sewage Treatment Plant, 29433 Batam, Indonesia
}

\begin{abstract}
The reclamation of wastewater as clean water resource is essential in the concept of water conservation. In industries, this will also lead to overall plant operational cost reduction. In this study, a pilot-scale surface-flow constructed wetland system filled with water hyacinth was used to treat effluent from existing sewage treatment plant at Batamindo Industrial Park. The sewage treatment plant effluent with quality fulfilling the regulation of Indonesian Ministry of Environment No.5/2014/XLVII-Group I was treated further to meet the raw water quality standard of Class I defined by Indonesian Government Regulation No.82/2001 as potable water resource. The system was able to maintain high chemical oxygen demand removal efficiency of around $80 \%$ from initial value of $100 \mathrm{mg} / \mathrm{L}$ in sewage treatment plant effluent despite the change of flow rate from 10 to $40 \mathrm{~m}^{3} /$ day (corresponding to hydraulic retention time of 2 to 0.5 days in constructed wetland respectively). The constructed wetland could successfully increase dissolved oxygen concentration, remove coliform bacteria and improve clarity (reduce turbidity) of water while maintaining neutral $\mathrm{pH}$ and low TSS values. Some additional post-treatments such as simple aeration and ultraviolet irradiation may improve the water quality further to meet the Class I Standard of potable water resource.
\end{abstract}

\section{Introduction}

Constructed wetland has been studied and used extensively in treatment of various kind of wastewater, not only those containing organic compounds or plant nutrients such as municipal sewage and agricultural wastewater but also wastewater containing heavy metals or other hazardous compounds such as metallurgic industry, chemical industry, landfill leachate and so on [1]. Guidelines from United States Environmental Protection Agency (US-EPA) for municipal wastewater treatment using constructed wetland have been issued as early as 1988 [2]. A handbook of constructed wetlands for agricultural wastewater, domestic wastewater, coal mine drainage, and storm water was provided by United States Department of Agriculture cooperating with USEPA and Pennsylvania Department of Environmental Resources [3]. During the years, other guidelines related to constructed wetland for treatment of specific wastewaters have also been published by cities and other agencies around the world [4-7]. It is fairly safe to say that wetland treatment is an already established method to treat various kind of wastewater.

As in natural wetland system that is well known for the water purification capability, constructed wetland is actually comprised of several units such as plants, microorganisms and soil that take part in water purifying process physically, chemically and biologically. Plant absorbs both organic and inorganic compounds in water into its biomass. Microorganism can accelerate the decomposition of organic compounds due to its metabolism. Some pathogens existing in water can also be removed when the water comes into contact with natural microorganisms living in the wetland. Soil can serve as filter to remove solid particles, as ion exchanger to trap cations or anions in water, and also as media to facilitate many kinds of chemical and biological reactions occurring in water. Because of these characteristics, wetland treatment system is capable to process almost any kind of wastewater removing both the organic and inorganic contaminants as long as the toxicity of the contaminants is within tolerance of the ecosystem inside the wetland. With sufficient nutrients in wastewater, no chemical addition is necessary to operate the wetland treatment system. Constructed wetland is also generally constructed to achieve gravity flow so that no energy is required for pumping system inside the wetland. The only disadvantage of wetland treatment system is the relatively slow treatment process that requires large area to achieve large-scale water or wastewater treatment.

According to the position of water layer, constructed wetland can be categorized as surface-flow wetland with exposed water layer flowing above soil layer and subsurface-flow wetland with water layer flowing beneath the surface of soil layer. Both types have their own advantages and disadvantages. Surface-flow wetlands may be easily aerated due to photosynthesis processes and direct contact of water with the atmosphere, while subsurface-flow wetlands may be suitable for heavier load of contaminants due to additional filtration system of soil. Subsurface-flow

\footnotetext{
${ }^{*}$ Corresponding author: chrissalim@gmail.com
} 
wetlands may require larger area than surface-flow wetlands due to the volume occupied by soil media that could reach almost $50 \%$ of total volume.

Until now, most of the studies and practices relating to wastewater treatment using constructed wetland were aimed at safe disposal of treated effluent to the environment or reuse of the treated effluent as a nonpotable water resource such as water for irrigation that will eventually return to the environment. Some cities such as Orlando utilize constructed wetlands that are large enough to reclaim municipal wastewater as nonpotable water resource [8-9]. The quality of water coming out of a wetland depends on the treatment capacity of the wetland that could be affected by several factors such as the wetland area, type of vegetation, hydraulic retention time and so on. Therefore, it is considered possible to integrate constructed wetland into wastewater treatment system to provide effluent with quality high enough for reuse in water treatment system that provides potable water.

In this study, pilot-scale of surface-flow wetland was built to treat effluent from sewage treatment plant (STP) of Batamindo Industrial Park (BIP) as initial phase of BIP water reclamation project scheme to reduce water intake from surrounding environment while increasing water recycling and reuse. The objective in this study was to evaluate the wetland performance in improving water quality of STP effluent into raw water resource for potable use. Performance of the constructed wetland was observed at several different operational conditions that include water depth, flow rate and soil layer. Water quality of the effluent from wetland was monitored and compared to the water quality of raw water resource for potable use defined in regulation of Indonesian Government No.82/2001 Water Standard Class I (PP $82 / 2001 /$ Class I) [10].

\section{Experimental methods}

\subsection{Constructed wetland design}

Flow diagram of STP and wetland system is shown in Figure 1. BIP domestic wastewater being treated at STP using sequential batch reactor (SBR) was flowed into intermediate collection tank prior to entering the wetland to achieve constant flow rate. After that, effluent from wetland was collected at the outlet for sampling and disposal.

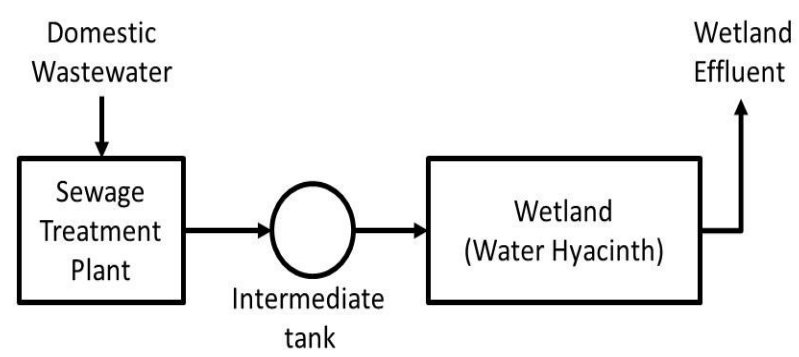

Fig. 1. Flow diagram of STP and wetland system
Two open concrete ponds with dimension of $5 \mathrm{~m} \times 10$ $\mathrm{m} \times 1 \mathrm{~m}$ (width $\times$ length $\mathrm{x}$ height) were used as the vessels to contain pilot-scale surface-flow wetlands operated with different conditions. Soil layer was laid out in the bottom with height of $0.4 \mathrm{~m}$. The outlet piping was arranged specifically to maintain water level at 0.2 or $0.4 \mathrm{~m}$ above the soil layer even during the raining period. Flow rate of STP effluent were adjusted to hydraulic retention time (HRT) of $0.5,1$ or 2 days. Plant type use in the wetland was Eichhornia crassipes, known commonly as water hyacinth. This type of aquatic plant is known for its resiliency and its survivability in contaminated water, and it is even classified as an invasive aquatic plant that often poses a threat in an open aquatic ecosystem.

\subsection{Sampling and analysis}

Influent and effluent of wetland were sampled daily and analyzed for several parameters, i.e., chemical oxygen demand (COD), total suspended solid (TSS), dissolved oxygen (DO) and turbidity. COD was measured using colorimetry with potassium permanganate method, while TSS and turbidity was measured using spectrophotometry (Spectroquant Nova 60, Merck). Dissolved oxygen was measured using portable DO meter (Cyberscan DO 300 Series). Periodically, full water quality analyses of STP and wetland effluents were carried out according to parameters in regulation of Indonesian Environmental Ministry (PerMenLH 5/2014/XLVII-Group I) [11] (for domestic wastewater) and PP 82/2001/Class I (for potable use raw water resource), respectively.

Plant growth in the wetland was also observed visually. The plant number was counted manually starting from the initial number of 30 units in the $50 \mathrm{~m}^{2}$ pond area.

\section{Results and discussion}

\subsection{Plant growth}

Figure 2 shows the increase of plant count of water hyacinth in the wetland during the experiment. The initial number was 30 units and increased significantly up to 680 units in 36 days. This significant growth of water hyacinth was sustained only by nutrients existing in STP effluent without any additional nutrients from external source. Maximum growth rate calculated from this data is about 0.5 unit of water hyacinth per square meter of wetland per day.

The number of plant did not show any significant increase afterwards due to saturation in the $5 \times 10 \mathrm{~m}^{2}$ wetland pond. Visual observation showed that some plants became submerged and withered. 


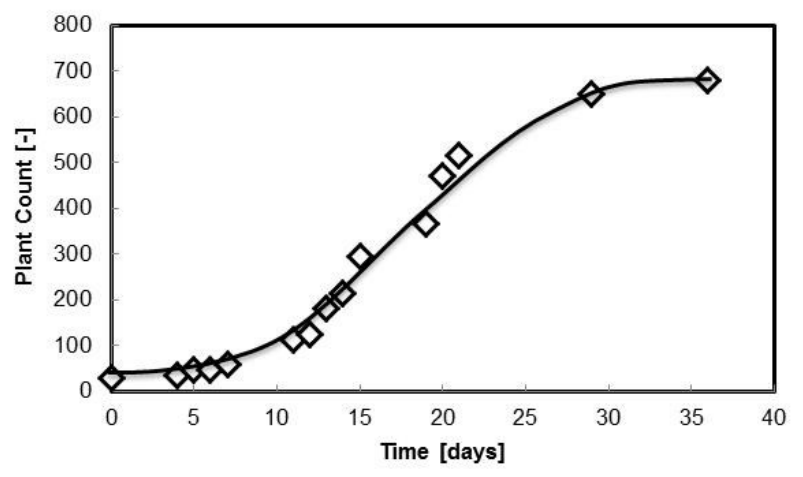

Fig. 2. Plant count of water hyacinth in the wetland

\section{$3.2 \mathrm{pH}, \mathrm{DO}, \mathrm{TSS}$ and turbidity measurements}

The results of $\mathrm{pH}$, DO, TSS and turbidity measurements are shown in Figure 3-6. The water quality data during plant growth period (0-29 days) showed some fluctuation (data not shown) due to a few internal and external factors such as growth of other type of plants (lemna and pistia) and disturbances to water in pond during observations. The results shown here is those from steady-state period after the number of water hyacinth reached saturation ( $>29$ days) and the pond is fully covered only by water hyacinths.

The dashed lines in Figure 3-5 indicate the regulation standard limits for class I raw water resource with $\mathrm{pH}$ value between 6 and 9, DO value of $6 \mathrm{mg} / \mathrm{L}$ or higher and TSS value of $50 \mathrm{mg} / \mathrm{L}$ or higher.

$\mathrm{pH}$ value was maintained near neutral throughout the experiment (Figure 3). Although a spike of $\mathrm{pH}$ value (data not shown) reaching nearly 10 was observed during plant growth period (0-29 days), the value decreased and stabilized quickly after the plants' number has reached saturation. Further study is necessary to confirm and reveal the mechanism of $\mathrm{pH}$ increase during plant growth period.

DO value of wetland influent showed some fluctuation that could be caused by the fluctuation in the STP at Batamindo which is utilizing two SBR units for the treatment of domestic wastewater (Figure 4 and 5). In fact, the full water quality analyses carried out periodically for both SBR units at the same time showed quite different values for those parameters (Table 1). Despite the fluctuation, the wetland can improve and stabilize the DO concentration from one as low as 2 $\mathrm{mg} / \mathrm{L}$ up to around $5-6 \mathrm{mg} / \mathrm{L}$. During the treatment, organic compounds contributing to BOD and COD values were absorbed and/or degraded, thus reducing the oxygen demand in the water and increasing the DO concentration. A spike of DO concentration was also observed (data not shown) during plant growth period (0-29 days), although the mechanism is yet to be studied. The DO value is actually balanced between several processes in the water that includes photosynthesis processes and oxygen transfer from atmosphere that increase DO, and aerobic metabolisms of microorganisms and reaction of oxygen with reduced compounds such as sulfides that decrease DO. During the experiment, the DO value in the effluent could stabilize at around 6 , the minimum value required to meet the raw water quality standards for potable use. With simple aeration method such as cascade aerator, the DO value can be improved further up to nearly the saturation value of around $8 \mathrm{mg} / \mathrm{L}$ at $25^{\circ} \mathrm{C}$.

Despite the fluctuation, TSS value and turbidity were also able to be lowered and maintained at a minimum level (Figure 5 and 6), thus improving the clarity of the wetland effluent. The contributor of TSS and turbidity in the water was mainly the solid biomass sludge residue after settling and clarifying processes in SBR. Given enough treatment time inside the wetland, the biodegradable solid residue from SBR can settle down to the bottom or be dissolved and utilized in metabolism processes. Although turbidity is not included in the water quality standards, it may affect the effectiveness of some post-treatment processes of the wetland treated water such as disinfection process. The turbidity is also one of the aesthetic parameters in water quality.

\subsection{Effect of hydraulic retention time}

The flow rate of influent at Pond 2 was adjusted from 10 to $20 \mathrm{~m}^{3} /$ day and then to $40 \mathrm{~m}^{3} /$ day on day $29^{\text {th }}$ and $56^{\text {th }}$, respectively. This corresponds to decreasing HRT from 2 days to 0.5 day. The decrease of HRT (or the increase of influent flow rate) did not reduce the water quality in terms of $\mathrm{pH}, \mathrm{DO}$, TSS and turbidity. With a lower HRT (or a higher flow rate), the treatment capacity of the wetland is increased, meaning that smaller wetland area is necessary to treat certain amount of wastewater, or in other words, larger amount of wastewater can be treated using a certain area of wetland.



Fig. 3. $\mathrm{pH}$ value of influent and effluent in wetland

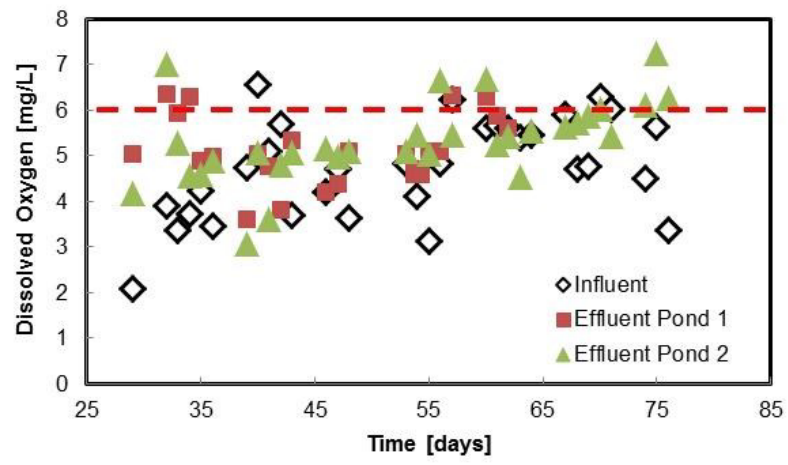

Fig. 4. DO value of influent and effluent in wetland 


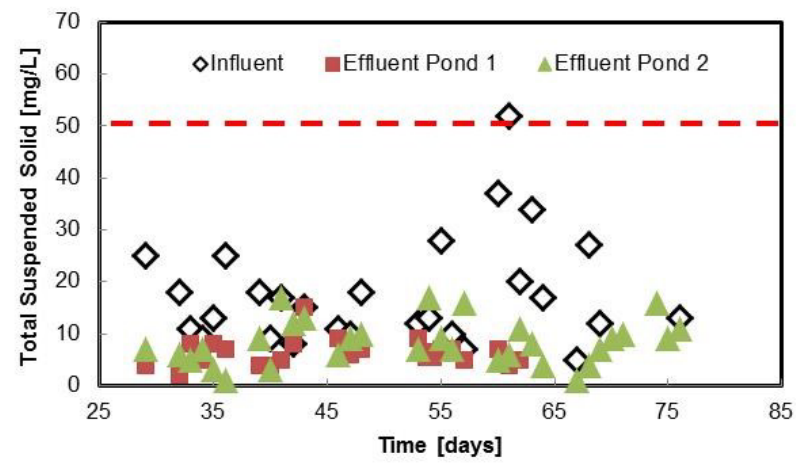

Fig. 5. TSS value of influent and effluent in wetland

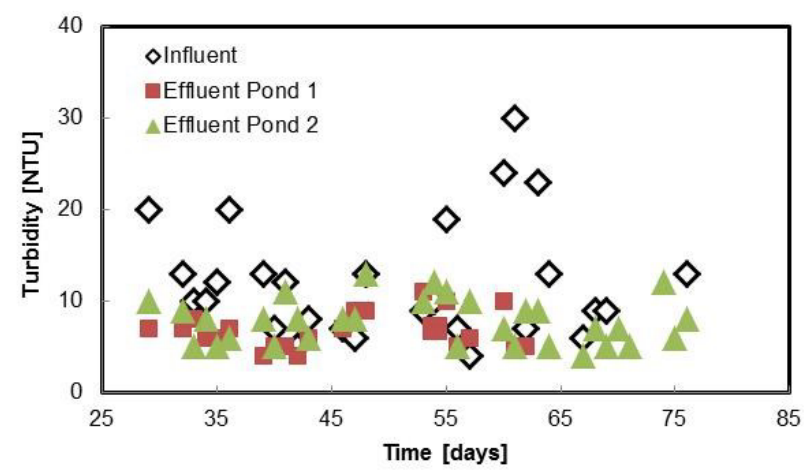

Fig. 6. Turbidity of influent and effluent in wetland

Table 1. Water Quality of SBR Effluents

\begin{tabular}{|c|c|c|}
\hline Parameters & SBR 1 & SBR 2 \\
\hline TSS [mg/L] & 16 & 65 \\
\hline Turbidity [NTU] & 3 & 25 \\
\hline BOD [mg/L] & 48 & 27 \\
\hline COD [mg/L] & 112 & 63 \\
\hline Ammonia [mg/L] & 3.10 & 3.24 \\
\hline $\begin{array}{c}E . \text { coli } \\
\text { [MPN/100 ml] }\end{array}$ & 2,000 & 2,000 \\
\hline $\begin{array}{c}\text { Total Coliform } \\
\text { [MPN/100 ml] }\end{array}$ & 2,400 & 2,400 \\
\hline
\end{tabular}

\subsection{Comparison of effluent quality with water quality standards}

Table 2 shows the comparison of wetland effluent quality and the standards in PP 82/2001 for class I raw water resource for potable use. Comparison of Table 1 and 2 shows that water quality of wetland effluent was improved considerably where BOD were lowered significantly from $48 \mathrm{mg} / \mathrm{L}$ to a range of $5-10 \mathrm{mg} / \mathrm{L}$ while COD were lowered from $112 \mathrm{mg} / \mathrm{L}$ to a range of 11-34 mg/L. The wetland could also suppress the number of pathogenic microorganisms as shown by the minimization of the number of Escherichia coli and Total Coliform.

There are, however, some parameters that still require improvements in order for the wetland effluent to reach Class I raw water resource standards, i.e., BOD, $\mathrm{COD}$, ammonia and hydrogen sulfide $\left(\mathrm{H}_{2} \mathrm{~S}\right)$ concentrations. It is possible that $\mathrm{BOD}$ and $\mathrm{COD}$ values were fluctuating at higher levels than standards and could not be reduced further because of metabolisms of organisms inside the wetland that not only consume organic compounds contributing to BOD and COD values but also produce them as a part of the metabolisms.

Table 2. Water Quality of Wetland Effluent

\begin{tabular}{|c|c|c|}
\hline Parameters & Effluent & $\begin{array}{c}\text { Class I raw } \\
\text { water resource } \\
\text { standards }\end{array}$ \\
\hline $\mathrm{BOD}[\mathrm{mg} / \mathrm{L}]$ & $5-10$ & $\leq 2$ \\
\hline $\mathrm{COD}[\mathrm{mg} / \mathrm{L}]$ & $11-34$ & $\leq 10$ \\
\hline $\mathrm{Ammonia}[\mathrm{mg} / \mathrm{L}]$ & 0.65 & $\leq 0.5$ \\
\hline $\mathrm{H}_{2} \mathrm{~S}[\mathrm{mg} / \mathrm{L}]$ & 0.050 & $\leq 0.002$ \\
\hline $\begin{array}{c}E . \text { coli } \\
\text { MPN/100 ml }]\end{array}$ & 3 & $\leq 100$ \\
\hline $\begin{array}{c}\text { Total Coliform } \\
{[\mathrm{MPN} / 100 \mathrm{ml}]}\end{array}$ & 15 & $\leq 1000$ \\
\hline
\end{tabular}

Although the levels were very low, the existence of ammonia and hydrogen sulfide in water may indicate the possibility of an anaerobic condition occurring inside the wetland. Since the whole pond surface was fully covered by water hyacinth and no aeration system installed in the wetland, it is possible that anaerobic condition prevails at bottom layer of the sediment. The activity of microorganisms at this condition will certainly produce reduced compounds such as ammonia, hydrogen sulfide and methane.

These parameters may be improved further using post-treatment methods such as simple aeration to remove excess ammonia, $\mathrm{H}_{2} \mathrm{~S}$, and other volatile organic compounds contributing to BOD, COD levels. Photolysis using ultraviolet irradiation or photocatalysis such as $\mathrm{UV} / \mathrm{TiO}_{2}$ system [12] may also be an option to improve these parameters.

\subsection{Operational conditions and maintenance}

The optimum operational conditions of the wetland in this study are yet to be investigated further. For example, DO levels during the fast growing period between day 10 and 30 (Figure 1) showed high values that were close to saturation (around $8 \mathrm{mg} / \mathrm{L}$ at $25^{\circ} \mathrm{C}$ ). This could be caused by wider exposure of water surface to the surrounding air when the surface was not yet fully covered by water hyacinth and also by photosynthesis activities happening beneath the surface, both providing more oxygen into the water. Usual practice of surfaceflow constructed wetland will leave a part of the surface exposed to air and sunlight, although the portion is yet to be determined according to some factors such as vegetation type, optimum plant count per unit area (planting density), water depth, etc.

By controlling the plant density, it is also possible to maintain an optimum consumption rate of organic compounds that will reflect on higher removal of BOD, COD, ammonia, nitrites, nitrates and other contaminants that serve as nutrients for the plant and other aquatic organisms. On the other hand, constructed wetland using water hyacinth or similar plant that grow and multiply very fast will certainly face a problem in the disposal of the by-product, i.e., the excess number of plants. For 
example, simple calculation using the maximum plant growth rate of around 0.5 unit per square meter per day shows that the treatment of $1000 \mathrm{~m}^{2} /$ day of STP effluent using $1000 \mathrm{~m}^{2}$ of wetland (HRT $=0.5$ day) would produce 500 units of water hyacinth daily. Therefore, it is also necessary to find a suitable way to utilize this byproduct. Some studies related to utilization of water hyacinth proposed methods such as biogas production [13], fiber extraction [14] and animal fodder [15].

\section{Conclusions}

The evaluation of surface-flow wetland treatment performance on sewage treatment plant effluent at Batamindo Industrial Park using water hyacinth has been carried out and the ability of this wetland treatment method to improve water quality of STP effluent was confirmed. Post-treatment using simple aeration and ultraviolet irradiation may be necessary to improve further the water quality of wetland effluent so that it can fulfill the requirement standards of PP 82/2001/Class I raw water resource for potable use. Excess water hyacinth in this wetland treatment can be a benefit if suitable industry can be implemented for its utilization, whether as energy or material resources.

The next phase of this study will be focusing on treatment of effluent from industrial wastewater treatment plant at Batamindo Industrial Park. Due to its characteristics, the WWTP effluent may prove to be more challenging than the sewage treatment plant effluent discussed in this paper, in which case a more efficient wetland treatment method will be necessary to achieve the expected result.

This pilot study of surface-flow wetland for water reclamation at Batamindo Industrial Park was fully supported by PT. Batamindo Investment Cakrawala as initial phase towards full-scale implementation on water reclamation of domestic and industrial wastewater treatment plant effluents.

\section{References}

1. J. Vymazal, Water, 2, 530-549 (2010)

2. U.S. EPA, EPA/625/1-88/022 (1988)

3. U.S. EPA, EPA 843B00005 (1995)

4. U.S. EPA, Manual, EPA/625/R-99/010 (2000)

5. UN-HABITAT, Constructed Wetlands Manual (2008)

6. Melbourne Water, Constructed Wetlands Guidelines (2010)

7. City of Saskatoon, Wetland Design Guidelines (2014)

8. S. Glass, J. Thullen, J. Sartoris, R. Roline, General Technical Report RM-GTR-272, 243-252 (1995)

9. K. Rothfeld, M. Sees, Orlando Easterly Wetlands Annual Report 2013 (2013)

10. Regulation of Indonesian Government PP 82/2001

11. Regulation of Indonesian Ministry of Environment PerMenLH 5/2014

12. M.N. Chong, B. Jin, C.W.K. Chow, C. Saint, Water Res, 44, 2997-3027 (2010)

13. P. Njogu, R. Kinyua, P. Muthoni, Y. Nemoto, EPE, 7, 209-216 (2015)

14. N.F. Ramirez, Y.S. Hernandez, J.C. de Leon, S.R.Vasquez Garcia, L.D. Lvova, L.G. Gonzalez, Fibers Polym, 16, 196-200 (2015)

15. C. Polprasert, N. Kongsricharoem, W. Kanjanaprapin, Waste Manag. Res., 12, 3-11 (1994) 